\title{
Workplace-Oriented Definition of Translation Competence
}

\author{
EL-HUSSAIN ALY
}

\section{Abstract}

This study aims at exploring workplace-oriented translation competence, and investigating to what extent students of translation are aware of that competence. Workplace-oriented translation competence refers to attitudes, abilities, skills and knowledge sets required to maintain a career of a successful professional translator in the market. In other words, it has to do with the level of professionalism a translator has. In order to answer questions related to the above aim, the study explores the views of working translators as well as students of translation through interviews and questionnaires. Out of the interviews, a list of skills and knowledge sets clarifying the workplace-oriented competence was produced. That list was used to design the questionnaire, the results of which indicate that students of translation are aware of the workplaceoriented translation competence. The study has clear implications for the translation curriculum and teaching methodology.

Keywords: Translation Competence, Translation Training and Education.

\section{Introduction}

The aim of this study is to explore workplace-oriented translation competence, and whether or not Egyptian students of translation are aware of components of that competence. Translation competence can be generally defined as "the underlying system of knowledge, abilities and attitudes required to be able to translate" (PACTE Group, 2005, Translation Competence, para 2). The above definition underlies a distinction between two sets of competence: (a) translation production competence, and (b) workplace-oriented 
translation competence. The translation production competence is directly related to the mental process of translation such as the command of language, ability to perform language transfer, ability to deal with different texts, etc. The workplace-oriented translation competence has to do with the level of professionalism a translator has. For example, a translator's professionalism can be evaluated in terms of the quality of translation produced within a deadline, his/her ability to maintain both quality and productivity, his/her ability to work collaboratively, etc.

The study focuses on workplace-oriented translation competence because this has attracted little attention in research; many translation competence models (e.g. Bell (1991), Schäffner (2000), Rydning (2002) etc. do not include any skill directly related to the market. In addition, workplaceoriented competence does not attract much attention in translation education and training, hence the gap between education and the skills required in the market (Kiraly 2005). As Loveluck (2012) explains:

The mismatch between the outputs of the education system and the needs of the job market is one of the key reasons behind the persistently high level of unemployment in Egypt, which is officially estimated at 12 per cent but generally assumed to be significantly higher. Unemployment is particularly high among the under-25s and among university graduates, who, according to estimates from a regional NGO, Injaz Al Arab, typically take five years to find a job (Loveluck 2012).

In Egyptian undergraduate education, the focus on theory solves the problem of teaching large classes as well as lack of equipment. Lecturing to a large audience makes it almost impossible to make use of any advantage of lecturing except presenting an overview of a topic. Assessment, in turn, as 
Hussein (2014) states, tends to reward students for memorization rather than for critical thinking, evaluation, etc. The result is that, Hussein (2014) claims, employers complain that these students' knowledge, work ethics and skills are below average.

This study focuses on workplace-oriented translation competence in an attempt to narrow the gap between translation education and the translation market. In order to define workplace-oriented translation competence, the study explores the views of working translators through interviews. In addition, a questionnaire is administered to students of translation in order to examine students' awareness of the components of workplace-oriented translation competence.

\section{Literature Review}

\subsection{Translation Competence}

Schäffner (2000) describes translation competence in terms of performing a particular translation assignment. She defines translation competence as "a complex notion which involves an awareness of and conscious reflection on all the relevant factors for the production of a target text (TT) that appropriately fulfills its specified function for its target addressees" (p. 146). EMT (2009) relates the translation competence not only to an assignment but also to how a whole institution perceives translation. They define translation competence as "the combination of aptitudes, knowledge, behaviour, and know-how necessary to carry out a given task under given conditions. This combination is recognised and legitimised by a responsible authority (institution, expert)" (p. $3)$.

\subsection{Models of Translation Competence}

\subsubsection{Psycholinguistic Models of Translation Competence}


For Bell (1991), Translation competence consists of four components. The first component has to do with the language system or knowledge of the rules of the code. The second component is sociolinguistic and deals with knowledge of language in context. The third focuses on the discourse level; it deals with the interaction of form and meaning in different genres. The last component is the strategic competence. It consists in the mastery of communication strategies, which compensate for any breakdown in any of the other competences.

Rydning (2002) believes that translation is a complex problemsolving activity that becomes possible due to the following components:

1. Declarative knowledge, i.e. knowing that,

2. Linguistic knowledge,

3. Cultural knowledge,

4. Procedural knowledge, i.e. knowing how,

5. Translation strategies,

6. Translation norms, and

7. Cognitive knowledge.

The above two models are descriptive, i.e. translation competence is described according to what professional translators actually do during the translation process.

\subsubsection{Functionalist Models of Translation Competence}

For Schäffner (2000), translation competence consists of six sub-competences: linguistic, cultural, textual, subject-specific, search and transfer. The major difference between this model and Bell (1991) and Rydning (2002) is transfer competence. Transfer competence refers to the ability to produce a target text which satisfies the specifications of a translation assignment. This is different from the strategic competence in Bell's (1991) model as the strategic competence facilitates 


\section{El-Hussain Aly}

communication without having to do with changes in the target text to satisfy a certain brief.

PACTE (2003, 2005) have developed a model of translation competence on the basis of empirical evidence. Translation competence as described in the model consists of the following sub-competences:

1. Bilingual sub-competence (command of two languages);

2. Extra-linguistic sub-competence (bicultural knowledge, encyclopedic knowledge, and knowledge of specific subject matter);

3. Knowledge about translation sub-competence (knowledge about translation and translation profession);

4. Instrumental sub-competence (research skills on hard and soft resources);

5. Strategic sub-competence (translation problemsolving competence); and

6. Psycho-physiological components (cognitive such as memory, attention etc., attitudinal such as perseverance, curiosity etc., and abilities such as creativity).

Again what is distinctive about functionalist models is the ability to satisfy clients' needs. Translation is not seen as a practice isolated from the community. However, functionalist models do not include any skills related to translation provision. They focus on the skills required to produce a translation for a client, but they do not speak about delivering the translation to the client. For example, they include skills to 
satisfy the clients' needs (during a translation, e.g. translating in simple language for children), but they do not include skills to check clients' satisfaction or long relationship between translator and client.

\subsubsection{Market-Oriented Models of Translation Competence}

The EMT model (2009) has been developed with the purpose of implementing a European reference framework for a Master's in Translation. The model relates theoretical models to the requirements of the professional market. Translation competence as described in this model consists of the following types of competence:

1. Translation service provision competence,

2. Language competence,

3. Intercultural competence,

4. Information mining competence,

5. Thematic competence, and

6. Technological competence,

The major difference between this model and the above models is the translation service provision competence. The translation service provision competence includes awareness of the social role of the translator, knowing how to follow market requirements, knowing how to organize approaches to clients, knowing how to negotiate with clients, knowing how to clarify the purpose of the translation, knowing how to manage time, knowing the standards applicable to the provision of a translation service, and knowing how to comply with professional ethics.

\section{Towards a Comprehensive Model of Translation Competence}

The above models (particularly PACTE, 2005 and EMT, 2009) can be summarized in one model that includes three types of 


\section{El-Hussain Aly}

translation competence. These are (a) general competence, (b) translation production competence, and (c) workplace-oriented translation competence.

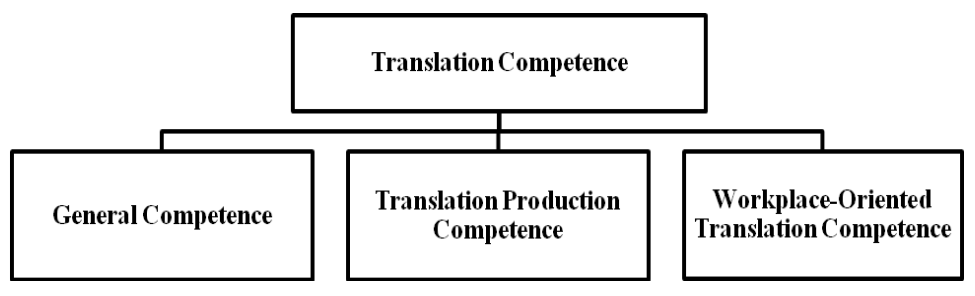

Figure 1: Translation Competence

\subsection{General Competence}

General competence consists of knowledge sets and skills which are general because they are not specific to the translation profession. For example, a teacher of English may also require the components of the general competence. The general competence includes linguistic competence, intercultural competence, ability to use hard and soft copy resources, general background knowledge, and specialist knowledge (of the subject matter of the source text).

\subsection{Translation Production Competence}

The general competence is not enough to produce a translation. In order to produce an optimal translation, one would need to employ mental translation strategies, knowledge sets, and skills that are directly related to the process of translation. These mental translation strategies, knowledge sets, and skills constitute the Translation Production Competence. It includes ability to perform language transfer, ability to deal with different texts, knowledge and awareness of the various translation issues 
and theories, and ability to produce a target text that serves a particular purpose (in terms of structure, terminology, register, etc.).

\subsection{Workplace-Oriented Translation Competence}

The general competence and the translation production competence may enable one to produce an optimal translation, but it may not necessarily enable one to be a successful translator in the market. In order to have the career and reputation of a successful professional translator, one needs workplace-oriented translation competence. Workplace-oriented translation competence has to do with the level of professionalism a translator has. For example, a translator's professionalism can be evaluated in terms of long relationship with and satisfaction of clients.

It is noteworthy that the three types of competences overlap. For example, workplace-oriented translation competence cannot be separated from translation production competence. In fact, it is the quality in the first place that contributes to professionalism. Therefore, the ability to produce a high quality translation within tight deadlines is difficult to separate from translator's linguistic knowledge and ability to transfer meaning between two languages.

\section{Research Questions}

The study attempts to answer two main questions:

(a) What are the components of workplace-oriented translation competence?

(b) To what extent are Egyptian students of translation aware of the components of workplace-oriented translation competence? 


\section{Methodology}

In order to explore the components of workplace-oriented translation competence, and investigate students' awareness of these components, two tools were used: (a) interviews, and (b) questionnaires.

\subsection{Interviews}

The purpose of the interviews was to identify the components of workplace-oriented translation competence. Nine people were interviewed. They are both male and female working translators. All the interviews were face to face with the exception of the interview with senior reviser at the UN which was an e-mail interview.

The working translators were two revisers at the $\mathrm{UN}$, one contractual translator by the UN, one contractual translator by the IMF, two translators at the Egyptian Tax Authority, and three freelance translators. They all have more than 15 years' experience with the exception of one freelance translator whose experience was less than 15 and more than 10 years. Three of the participants supervise junior translators, whereas, the other six do not. The following table includes the details of the working translators who participated in the interviews:

\begin{tabular}{|l|c|c|c|c|}
\hline Participants & Gender & Position & $\begin{array}{c}\text { Years of } \\
\text { experience in } \\
\text { the market of } \\
\text { translation }\end{array}$ & $\begin{array}{c}\text { Supervised } \\
\text { Junior } \\
\text { Translators }\end{array}$ \\
\hline Participant 1 & Male & $\begin{array}{c}\text { Reviser at the United } \\
\text { Nations, Vienna } \\
\text { Office }\end{array}$ & More than 15 & YES \\
\hline Participant 2 & Female & $\begin{array}{c}\text { Senior reviser at the } \\
\text { United Nations, } \\
\text { Vienna Office }\end{array}$ & More than 15 & YES \\
\hline Participant 3 & Male & $\begin{array}{c}\text { Contractual } \\
\text { translator by the UN }\end{array}$ & More than 15 & YES \\
\hline Participant 4 & Male & Contractual & More than 15 & NO \\
\hline
\end{tabular}


Workplace-Oriented Definition of Translation Competence

\begin{tabular}{|l|c|c|l|c|}
\hline & & $\begin{array}{c}\text { translator by the } \\
\text { IMF }\end{array}$ & \\
\hline Participant 5 & Female & $\begin{array}{c}\text { Translator at the } \\
\text { Egyptian Tax } \\
\text { Authority }\end{array}$ & More than 15 & NO \\
\hline Participant 6 & Female & $\begin{array}{c}\text { Translator at the } \\
\text { Egyptian Tax } \\
\text { Authority }\end{array}$ & More than 15 & NO \\
\hline Participant 7 & Male & Freelance translator & More than 15 & NO \\
\hline Participant 8 & Male & Freelance translator & More than 15 & NO \\
\hline Participant 9 & Female & Freelance translator & $\begin{array}{c}\text { Between 10 } \\
\text { and 15 }\end{array}$ & NO \\
\hline
\end{tabular}

Table 1: Working Translators Interviewed

All the interviews were semi-structured. They included variations on four main questions:

A) What kind of translators do universities need to graduate?

B) How can one close the gap between translation education/training and the translation market?

C) What competences should translation education and training contain?

D) What are the differences between a trainee translator and a professional translator?

\subsection{Questionnaires}

The questionnaires were based on the results of the interviews. The purpose of the interviews was to identify the components of workplace-oriented translation competence. After identifying these components, the questionnaires aimed at investigating students' awareness of those components.

A total of 72 recent graduates and undergraduates of translation, both male and female, participated in the questionnaires. Forty participants were enrolled at the different 
translation courses at the School of Continuing Education of the American University in Cairo. The following table includes details of the participants:

\begin{tabular}{|l|l|l|l|}
\hline Participants & $\begin{array}{l}\text { Fresh } \\
\text { Graduates }\end{array}$ & Undergraduates & Total \\
\hline $\begin{array}{l}\text { Learners enrolled at } \\
\text { the School of } \\
\begin{array}{l}\text { Continuing } \\
\text { Education }\end{array}\end{array}$ & 25 & 15 & 40 \\
\hline $\begin{array}{l}\text { Government } \\
\text { university students }\end{array}$ & 12 & 20 & 32 \\
\hline TOTAL & 37 & 35 & 72 \\
\hline
\end{tabular}

Table 3: Questionnaire Participants

The questionnaire (see Appendix A) includes nine statements. The participants were asked to respond to the statements with one of five statuses: strongly agree, agree, not sure, disagree, and strongly disagree.

\section{Results and Discussion}

\subsection{Components of Workplace-Oriented Translation Competence}

The results of the two interviews with UN revisers are very interesting. In the face-to-face interview with the UN reviser, it was explained that the main difference between a trainee translator and a professional translator is prioritizing the work particularly when asked to produce a translation within a tight deadline. In addition, team-work, communication, planning and organizing, commitment to continuous learning, and technological awareness were stressed. Furthermore, the UN reviser explained that it is important for the translator to edit and revise the work him/herself before submitting it to the editor/reviser. Similarly, in an exchange of emails with the senior UN reviser, she explained that, "unlike the clinically clear context of training, the professional world is rather 
Workplace-Oriented Definition of Translation Competence

messy, confusing and sometimes extremely stressful." Elaborating on this, she gave examples of the components of a professional situation: "the urgency of the job required, its length and variety, possibly its poor language, [and] potential conflicting feedback from client and/or revisers/editors." She concluded that, "it might be helpful to impress these facts in the trainees." She clarified that dealing with the confusing stressful professional world requires strong organization skills, and dealing with conflicting feedback from clients/revisers requires strong interpersonal and communication skills.

The interviews with the UN revisers included key themes:

- Prioritizing work

- Commitment to deadlines

- Team-work

- Planning

- Commitment to continuous learning

- Conflict resolution

- Revising and editing own work before submission.

The interviews with the other seven working translators included similar themes. The following table includes some interview excerpts and initial coding:

\begin{tabular}{|l|l|l|}
\hline $\begin{array}{l}\text { Sl. } \\
\text { No. }\end{array}$ & Excerpt & Initial Coding \\
\hline 1 & $\begin{array}{l}\text { Participant 9: The translator should consider the } \\
\text { time available for her to do the work before } \\
\text { accepting any new assignment. } \\
\text { Interviewer: So, should the translator ask for more } \\
\text { time before accepting the work? } \\
\text { Participant 9: Of course. Also, when a translator } \\
\text { asks for a different deadline, she should not ask for } \\
\text { much time, not only so as not to lose the client, but } \\
\text { also to free herself of the assignment and look for } \\
\text { another. }\end{array}$ & \\
\hline 2 & Participant 3: Beginners usually have limited & Networking \\
\hline
\end{tabular}




\begin{tabular}{|c|c|c|}
\hline & $\begin{array}{l}\text { relations. By time, they build relationship } \\
\text { networks. I do not recommend that they go directly } \\
\text { to the international market. I believe they should } \\
\text { spend some time in the local market. }\end{array}$ & \\
\hline 3 & $\begin{array}{l}\text { Participant 6: A professional translator can } \\
\text { choose the team, good at selecting the team... and } \\
\text { should choose people with the same competence } \\
\text { level. } \\
\text { Interviewer: What if the team is already formed } \\
\text { and she needs to work with that team? } \\
\text { Participant 6: Then a professional translator can } \\
\text { easily adapt to the spirit of the team. } \\
\text { Interviewer: And why a beginner cannot? } \\
\text { Participant 6: because the more professional and } \\
\text { experienced, the more you will be appreciated by } \\
\text { the team members, and professionalism helps } \\
\text { control many conflicts. } \\
\text { Interviewer: Can you give me an example? } \\
\text { Participant 6: It is easier to argue with a } \\
\text { professional about the accuracy of a translation } \\
\text { than with a beginner. }\end{array}$ & $\begin{array}{l}\text { Teamwork \& } \\
\text { Conflict } \\
\text { solving }\end{array}$ \\
\hline 4 & $\begin{array}{l}\text { Participant 4: The graduate should commit himself } \\
\text { to the code of ethics from the beginning. The more } \\
\text { professional a person is, the more he commits } \\
\text { himself to ethics. Any profession has ethics. In the } \\
\text { market, the golden rule of a translator is that he is } \\
\text { trusted, like a lawyer or a doctor. Also, the more } \\
\text { professional a translator is, the more accurate he } \\
\text { should be as professional translators know that we } \\
\text { translate what authors say and not what authors } \\
\text { want to say. }\end{array}$ & $\begin{array}{l}\text { Commitment } \\
\text { to ethics } \\
\text { including } \\
\text { confidentiality } \\
\text { and accuracy }\end{array}$ \\
\hline
\end{tabular}

Table 4: Workplace-Oriented Translation Competence: Interview Results The analysis of the interviews reveal the following components of workplace-oriented translation competence:

\section{Knowledge, Awareness and Commitment to Translation Ethics. This includes}

- commitment to high quality, which necessitates revising and editing own work before submission, 
- commitment to deadlines,

- commitment to continuous learning,

- confidentiality, and

- ability to set reasonable rates.

2. Organization skills. These include

- planning, and

- prioritizing the work.

3. Interpersonal skills. These include

- ability to work in teams,

- ability to solve conflicts,

- ability to work collaboratively, and

- networking.

The above list is supported by the competences required by international organizations such as the United Nations (UN) and American Association for Translators (ATA). For example, the translation competence as described on the UN website includes among other components:

- The ability to meet tight deadlines and maintain required productivity without sacrificing quality.

- The ability to establish and maintain effective working relations with people of different national, linguistic and cultural backgrounds with sensitivity and respect for diversity.

- The ability to work collaboratively with colleagues and to demonstrate a willingness to learn from others.

- Similarly, the translation competence described on ATA website is as follows: 
- Translation methods knowledge; Translation standards knowledge;

- Technical writing skills;

- Editing and proofreading skills;

- Ability to read a source language and write in a target language of a language pair;

- Ability to recognize and verify correspondence for a language pair;

- Ability to perform language transfer;

- Ability to follow specifications: audience, purpose and terminology;

- Translators ethical obligations; and

- Team-player, collegial, collaborative.

The two lists above include skills and knowledge sets related to interpersonal and organizational skills as well as knowledge and awareness of translators' ethics.

The framework proposed in this study is also in line with the framework suggested by EMT (2009). According to EMT (2009), translation service provision includes, among others, the following components: knowing how to plan and manage one's time, stress, work, budget and ongoing training; knowing how to comply with instructions, deadlines, commitments, and team organization; and knowing how to comply with professional ethics. The framework is also supported by the results of Lafeber (2012) who compares the training programs and translator skills in the UN systems.

\subsection{To what extent are Egyptian students of translation aware of workplace-oriented translation competence?}

Data collected to answer the second research question (To what extent Egyptian students of translation are aware of workplace-oriented translation competence?) indicate that 
students are aware of workplace-oriented translation competence and are looking forward to an education system that supports those components.

Table 5 below includes a summary of the responses in percentages. Agree and Strongly Agree are presented in one column to facilitate comparison with Disagree and Strongly Disagree, which are presented together as well in a single column. The table indicates that around two thirds of the participants $(69.5 \%)$ believe that commitment to deadlines contributes positively to the image of a good translator. In addition, the majority agree that abiding by code of ethics $(94.2 \%)$, including setting a reasonable rate for a translation assignment (80.5\%), is part of professionalism. It is a good idea then to assign at least an awareness session to such components in translation curricula.

\begin{tabular}{|l|l|l|l|l|}
\hline$\#$ & \multicolumn{1}{|c|}{ Statement } & $\begin{array}{c}\text { Strongly } \\
\text { Agree } \\
\text { \& } \\
\text { Agree }\end{array}$ & $\begin{array}{c}\text { Not } \\
\text { sure }\end{array}$ & $\begin{array}{c}\text { strongly } \\
\text { Disagree } \\
\text { \& } \\
\text { Disagree }\end{array}$ \\
\hline 1 & $\begin{array}{l}\text { Commitment to deadlines does } \\
\text { not have to do with my image } \\
\text { as a good translator. }\end{array}$ & $25 \%$ & $5.5 \%$ & $69.5 \%$ \\
\hline 2 & $\begin{array}{l}\text { Awareness of translation ethics } \\
\text { such as caring about accuracy } \\
\text { is part of professionalism. }\end{array}$ & $94.2 \%$ & $2.8 \%$ & $2.8 \%$ \\
\hline 3 & $\begin{array}{l}\text { Setting a reasonable rate for } \\
\text { translation is professional. }\end{array}$ & $80.5 \%$ & $8.3 \%$ & $11.1 \%$ \\
\hline
\end{tabular}

Table 5: Code of Ethics and Professionalism

Table 6 below focuses on revising and editing translation before submission. The majority disagree that editing as a skill is not important for a professional translator (97.2\%) or that as far as a translation will be revised and edited by a supervisor, the translator does not have to revise or edit it $(86.1 \%)$. Furthermore, the majority agree that learning how to evaluate 


\section{El-Hussain Aly}

one's translation (91.7\%) and learning how to revise and edit one's translation $(94.4 \%)$ contribute positively to professionalism.

\begin{tabular}{|l|l|l|l|l|}
\hline \# & \multicolumn{1}{|c|}{ Statement } & $\begin{array}{c}\text { Strongly } \\
\text { Agree \& } \\
\text { Agree }\end{array}$ & $\begin{array}{c}\text { Not } \\
\text { sure }\end{array}$ & $\begin{array}{c}\text { Strongly } \\
\text { Disagree \& } \\
\text { Disagree }\end{array}$ \\
\hline 1 & $\begin{array}{l}\text { Editing as a skill is not } \\
\text { important for a professional } \\
\text { translator. }\end{array}$ & 0 & $2.8 \%$ & $97.2 \%$ \\
\hline 2 & $\begin{array}{l}\text { As long as my work will be } \\
\text { revised and edited by others, I } \\
\text { do not have to revise and edit } \\
\text { it before submission. }\end{array}$ & $\begin{array}{l}\text { If I understand how a } \\
\text { translation is evaluated, I will } \\
\text { be able to produce a better } \\
\text { translation }\end{array}$ & $8.3 \%$ & $86.1 \%$ \\
\hline 4 & $\begin{array}{l}\text { Learning about how to revise } \\
\text { and edit my own translation } \\
\text { makes me professional. }\end{array}$ & $94.4 \%$ & $2.8 \%$ & $2.8 \%$ \\
\hline
\end{tabular}

Table 6: Revising and Editing

Table 7 deals with communication and professional relations in the market. Over half of the participants $(61.1 \%)$ agree that a good translator is a good communicator with others and that the more professional the translator becomes, the more contacts s/he will have with other translators, revisers and editors $(88.8 \%)$. The results indicate that a professional translator is supposed to be part of a network of translators, revisers, editors and clients. However, the study does not cover when, how or how frequent translators communicate within their networks. In addition, the results do not contradict Liu (2011) in which he concludes that some translators prefer not to communicate proactively with clients and end-users. 
Workplace-Oriented Definition of Translation Competence

\begin{tabular}{|l|l|l|l|l|}
\hline \# & \multicolumn{1}{|c|}{ Statement } & $\begin{array}{c}\text { Strongly } \\
\text { Agree } \\
\text { \& } \\
\text { Agree }\end{array}$ & $\begin{array}{c}\text { Not } \\
\text { sure }\end{array}$ & $\begin{array}{l}\text { Strongly } \\
\text { Disagree } \\
\text { \& } \\
\text { Disagree }\end{array}$ \\
\hline 1 & $\begin{array}{l}\text { A good translator is a good } \\
\text { team member and an effective } \\
\text { communicator with others. }\end{array}$ & $61.1 \%$ & $16.7 \%$ & $22.2 \%$ \\
\hline 2 & $\begin{array}{l}\text { The more professional, the } \\
\text { more I will have contact with } \\
\text { other translators, revisers, } \\
\text { editors etc. }\end{array}$ & $88.8 \%$ & $5.5 \%$ & $5.5 \%$ \\
\hline
\end{tabular}

Table 7: Professional Relations in the Workplace

After analysis of the questionnaires, the responses to two statements attracted my attention, and I have to conduct interviews to verify the responses. The following table includes the statements and the responses:

\begin{tabular}{|l|l|l|l|l|}
\hline \# & Statement & $\begin{array}{l}\text { Strongly } \\
\text { Agree } \\
\mathbf{\&} \\
\text { Agree }\end{array}$ & $\begin{array}{l}\text { Not } \\
\text { sure }\end{array}$ & $\begin{array}{l}\text { Strongly } \\
\text { Disagree } \\
\mathbf{8} \\
\text { Disagree }\end{array}$ \\
\hline 1 & $\begin{array}{l}\text { A good translator is a good } \\
\text { team member and an effective } \\
\text { communicator with others. }\end{array}$ & $61.1 \%$ & $16.7 \%$ & $22.2 \%$ \\
\hline 2 & $\begin{array}{l}\text { Commitment to deadlines } \\
\text { does not have to do with my } \\
\text { image as a good translator. }\end{array}$ & $25 \%$ & $5.5 \%$ & $69.5 \%$ \\
\hline
\end{tabular}

Table 8: Post Interviews to Explain Data for Two Statements

The relatively high percentage of Not-Sure (16.7\%) and Disagree $(22.2 \%)$ to the statement that a translator needs to be a good communicator with others requires, in my view, explanation. In an interview with five people who contributed to the above percentage, they agreed that a translator needs to be a good communicator and a team player only if $s /$ he is a project manager. On asking them when a translator can be a project manager, they said when s/he is experienced and senior. This means that they believe that a senior experienced 


\section{El-Hussain Aly}

translator should be able to communicate well with others and perform tasks within a team. This is interesting as it shows how they responded to the questionnaires from their own perspective as students, who can still produce good translations although their communication is limited to their supervisor.

Similarly, the learners viewed the second statement in terms of course assignments. They believed that being late in completing assignments had nothing to do with the quality of the work. I took the question to some professional translators who are also instructors at the School of Continuing Education of the American University in Cairo. One of them believed that a distinction should be made between commitment to deadline on the one hand and asking for extension from the start or early enough before the deadline on the other hand. Asking for extension from the start or early enough before the deadline does not have to do with the translator's image as he claimed. He mentioned that in one of the projects that should have been finished within one year, he asked for 6 months extension. To his surprise, the client said that the project was never finished within one year in the other languages it was translated to. This further information was interesting although it did not affect the results of the questionnaires as $69.5 \%$ believe that commitment to deadlines is part of professionalism.

In a nutshell, the analysis of the questionnaires indicates that students of translation are aware of the importance of workplace-oriented translation competence. They believe skills related to the market are necessary for translators if they want to promote their professionalism. This adds to the finding of Chodkiewicz \& Curie-Sklodowska (2012) who studied student translators' perception of the EMT framework and found that it is highly relevant to them. This leads to a discussion of the implications of the study on the translation classroom. 


\section{Implications}

This study has clear implications for the translation classroom. In order to prepare students of translation for the market of translation, the curriculum should include learning outcomes that are directly related to the translation market. In this case, the translation classroom can be seen as a bridge between translation theories and translation practice.

\subsection{Workplace-Oriented Translation Curricula}

As it is mentioned in the Introduction, this study attempts to narrow the gap between translation classroom and translation market by exploring the competence that is required in the market, and yet it is neglected in the classroom. However, in order to design a workplace-oriented curriculum, it is important to convert the competences into learning outcomes. The main difference between competences and learning outcomes is that competence refers to internal ability which is not possible to measure unless it is quantified in terms of behavior. Learning outcomes describe behavior that is measurable. This is usually reflected in the choice of an action verb in stating a learning outcome. The following table (Table 9 below) includes some competences and their corresponding learning outcomes as an example of the conversion of competences into learning outcomes:

\begin{tabular}{|c|c|c|c|}
\hline Sl. & $\begin{array}{c}\text { Skills \& } \\
\text { Knowledge Sets }\end{array}$ & Strategy & Learning Outcomes \\
\hline 1 & $\begin{array}{l}\text { Interpersonal skills. } \\
\text { These include } \\
\text { - ability to work in } \\
\text { teams, } \\
\text { - ability to work } \\
\text { collaboratively, } \\
\text { and } \\
\text { - networking. }\end{array}$ & $\begin{array}{l}\text { Engage with } \\
\text { the translation } \\
\text { environment }\end{array}$ & $\begin{array}{l}\text { - Communicate effectively } \\
\text { with clients } \\
\text { - Negotiate with clients } \\
\text { - Write professional CVs } \\
\text { and emails } \\
\text { - Work in real-life group } \\
\text { projects } \\
\text { - Perform tasks as a team } \\
\text { member }\end{array}$ \\
\hline
\end{tabular}




\begin{tabular}{|l|l|l|l|}
\hline 2 & Organization skills. & $\begin{array}{l}\text { Engage with } \\
\text { the translation } \\
\text { environment }\end{array}$ & $\begin{array}{l}\text { - Perform translation tasks } \\
\text { within tight deadlines }\end{array}$ \\
\hline 3 & $\begin{array}{l}\text { Knowledge, } \\
\text { awareness and } \\
\text { commitment to } \\
\text { translation ethics. }\end{array}$ & $\begin{array}{l}\text { Read various } \\
\text { translators' } \\
\text { code of ethics }\end{array}$ & $\begin{array}{l}\text { - Analyze different codes } \\
\text { of ethics } \\
\text { evaluate translation codes } \\
\text { of ethics }\end{array}$ \\
\hline
\end{tabular}

Table 9: Translating Competences into Learning Outcomes

As Table 9 indicates, in order for students to acquire interpersonal skills, they need to engage with the translation environment. This strategy (engagement with translation environment) can be accomplished, for example, by internship or by teamwork on large projects as part of coursework, both in and outside the physical classroom. In their internship or any other form of engagement with translation environment, students need to learn how to communicate effectively with clients, how to negotiate with clients, how to write professional CVs and emails, how to work in group projects, and how to perform tasks as a team member. The same strategy (engagement with translation environment) is used so that students may acquire organizational skills. As for knowledge, awareness and commitment to translation ethics, students need to read various translators' codes of ethics. In so-doing, students will be trained to analyze and evaluate the various codes of ethics.

\section{Translation Teaching Methodology within a Workplace- Oriented Translation Curriculum}

A translation curriculum should be conceived of as a bridge between theory and practice. Rather than focusing on memorization and retrieval of information, the precious time of the class is better saved for more active learning through problem-solving, critical thinking, collaborative learning etc. (Eric \& Martin 2013; Mangan 2013; Tucker 2012; Ullman 2014). In line with this, real-life projects (Kiraly 2005) and 
work placements or internships (Schäffner 2012) are important experience for students of translation. In addition to many other advantages, it makes clear to the students what skills they may still need in order to fit in the market of translation.

\section{Conclusion}

This study aims at exploring workplace-oriented translation competence by investigating students' awareness of that competence. To achieve that aim, nine working translators were interviewed and asked mainly about the skills and knowledge sets that translation education and training need to instill in the students so that they can easily fit into the market of translation. Out of these interviews, the workplace-oriented translation competence was described. It consists mainly of three main components:

(a) interpersonal skills, organizational skills, and (c) knowledge, awareness and commitment to translation ethics.

The interview results were used to design the questionnaire, the aim of which is to assess students' awareness of workplace-oriented translation competence. The results of the questionnaires indicated that the student translator see the workplace-oriented translation competence as an important component of translation training and education. The results have clear implication for translation curriculum and teaching methodology. The translation curriculum needs to include learning outcomes that are directly related to the market of translation such as communicating with clients and participating in real-life group projects. The strategy that can be used to achieve such learning outcomes is engagement with the translation environment. There are various forms of engagement with translation environment including internships and work placements. In order for the strategy of engagement with the translation environment to be effective, translation 


\section{El-Hussain Aly}

teaching methods should stress critical thinking, evaluation and creativity rather than simple practice of translation techniques and memorization.

\section{References}

BELL, R. T. 1991. Translation and translating: Theory and practice. London: Longman.

Chodkiewicz, M.; and CurIE-Sklodowska, M. 2012. The EMT Framework of Reference for Competences Applied to Translation: Perceptions by Professional and Student Translators. The Journal of Specialised Translation. 17. Retrieved March 2016 from

http://www.jostrans.org/issue17/art_chodkiewicz.pdf

EMT EXPERT GROUP. 2009. Competences for Professional Translators, Experts in Multilingual and Multimedia Communication. Retrieved March 2012, from http://ec.europa.eu/dgs/translation/programmes/emt/key_docu ments/emt_competences_translators_en.pdf

ERIC, B.; and MARTIN, H. 2014. A Flipped Classroom in Action. Science Teache. 80(2). 8.

Hussein, H. 2014. Can Egypt Afford Quality Education? AlAhram Weekly. (1193) 17 April, 2014. Retrieved April, 18 2014 from http://weekly.ahram.org.eg/News/5973/32/CanEgypt-afford-quality-education-.aspx

KIRALY, D. 2005. Project-Based Learning: a Case for Situated Translation. Meta: Translators'Journal 50(4). 1098-1111.

LAFERBER, A. 2012. Translation at Inter-governmental Organizations: The set of Skills and Knowledge Required and the Implications for Recruitment Testing. Ph.D. thesis, Universitat Rovira I Virgili. Tarragona: Intercultural Studies Group.

LIU, F. 2011. A Quantitative and Qualitative Inquiry into Translators' Visibility and Job-Related Happiness: The case of Greater China. Ph.D. thesis, Universitat Rovira I Virgili. Tarragona: Intercultural Studies Group. 
Workplace-Oriented Definition of Translation Competence

LovelucK, L. 2012. Education in Egypt: Key Challenges. Retrieved March 16, 2015 from http://www.chathamhouse.org/sites/files/chathamhouse/public /Research/Middle\%20East/0312egyptedu_background.pdf.

Mangan, K. 2013. Inside the Flipped Classroom. Chronicle of Higher Education. 60(5). B18-B21

PACTE. 2003. Building a Translation Competence Model. In Alves, F. (Ed.). Triangulating Translation: Perspectives in Process-Oriented Research. Amsterdam: John Benjamins. 4366

PACTE. 2005. Investigating Translation Competence: Conceptual and Methological Issues. Meta: Translators' Journal. 50(2). Retrieved Oct. 1-9, 2014, from http://www.erudit.org/revue/meta/2005/v50/n2/0110ar.html

RYDNING, A. F. 2002. Brief introduction to the Methodology of translog. Retrieved Oct. 25, 2014, from http://www.hf.no/kri/expertise/workshops/oslo/introduction.pd $\mathrm{f}$

SCHÄFFNER, C. 2012. Translation Competence: Training for the Real World. In S. Hubscher-Davidson and Borodo, M. (ed.). Global Trends in Translator and Interpreter Training. Mediation and Culture. London: Continuum. 30-44.

SCHÄFFNER, C.; and ADAB, B. 2000. Developing Translation Competence: Introduction. In C. Schäffner \& B. Adab (ed.). Developing Translation Competence. Benjamins Translation Library, vol. 38. Amsterdam: John Benjamins. vii-xvi.

TUCKER, B. 2012. The Flipped Classroom: Online Instruction At Home Frees Class Time For Learning. Education Next 12(1). Opposing Viewpoints in Context. Retrieved Dec. 29, 2014, from

http://ic.galegroup.com/ic/ovic/ViewpointsDetailsPage/Viewp ointsDetailsWindow?failOverType $=\&$ query $=\&$ prodId $=$ OVIC $\&$ windowstate=normal\&contentModules=\&displayquery $=\&$ mode $=$ view $\&$ displayGroupName $=$ Viewpoints $\& d v i S e$ lectedPage $=\&$ limiter $=\&$ currPage $=\&$ disableHighlighting $=$ true 
El-Hussain Aly

\&displayGroups=\&sortBy=\&zid=\&search_within_results $=\& p$ $=$ OVIC $\&$ action $=$ e $\&$ catId $=\&$ activityType $=\&$ scanId $=\&$ docume ntId=GALE\%7CEJ3010836205\&source=Bookmark\&u=asuni $\mathrm{v} \& \mathrm{jsid}=84 \mathrm{ae} 5 \mathrm{ac} 2454 \mathrm{ab} 1747 \mathrm{~d} 7 \mathrm{f36d} 145 \mathrm{~b} 634 \mathrm{fe}$

Ullman, E. 2013. Tips to Help Flip Your Classroom: Teachers Offer Their Strategies For Making The Most out of the Flipped Classroom Model. ASCD Education Update 55 (2), 15.

\section{WEBSITES}

http://www.unlanguage.org/Careers/Translators/Competency/d efault.aspx

http://www.atanet.org/

\section{APPENDIX A}

\section{Questionnaire}

This questionnaire is carried out as part of a study on workplace-oriented translation competence. Please indicate your opinion by putting a tick in the column that reflects your opinion. The second column includes a statement followed by five columns that forms a scale from strongly agree to strongly disagree.

Name (optional)

\begin{tabular}{|l|l|l|l|l|l|l|}
\hline $\mathbf{1}$ & Statement & $\begin{array}{l}\text { Strongly } \\
\text { Agree }\end{array}$ & Agree & $\begin{array}{l}\text { Not } \\
\text { Sure }\end{array}$ & Disagree & $\begin{array}{l}\text { Strongly } \\
\text { Disagree }\end{array}$ \\
\hline $\begin{array}{l}\text { to deadlines } \\
\text { does not have } \\
\text { to do with my } \\
\text { image as a } \\
\text { good } \\
\text { translator. }\end{array}$ & & & & & \\
\hline $\mathbf{2}$ & $\begin{array}{l}\text { A good } \\
\text { translator is a }\end{array}$ & & & & & \\
\hline
\end{tabular}


Workplace-Oriented Definition of Translation Competence

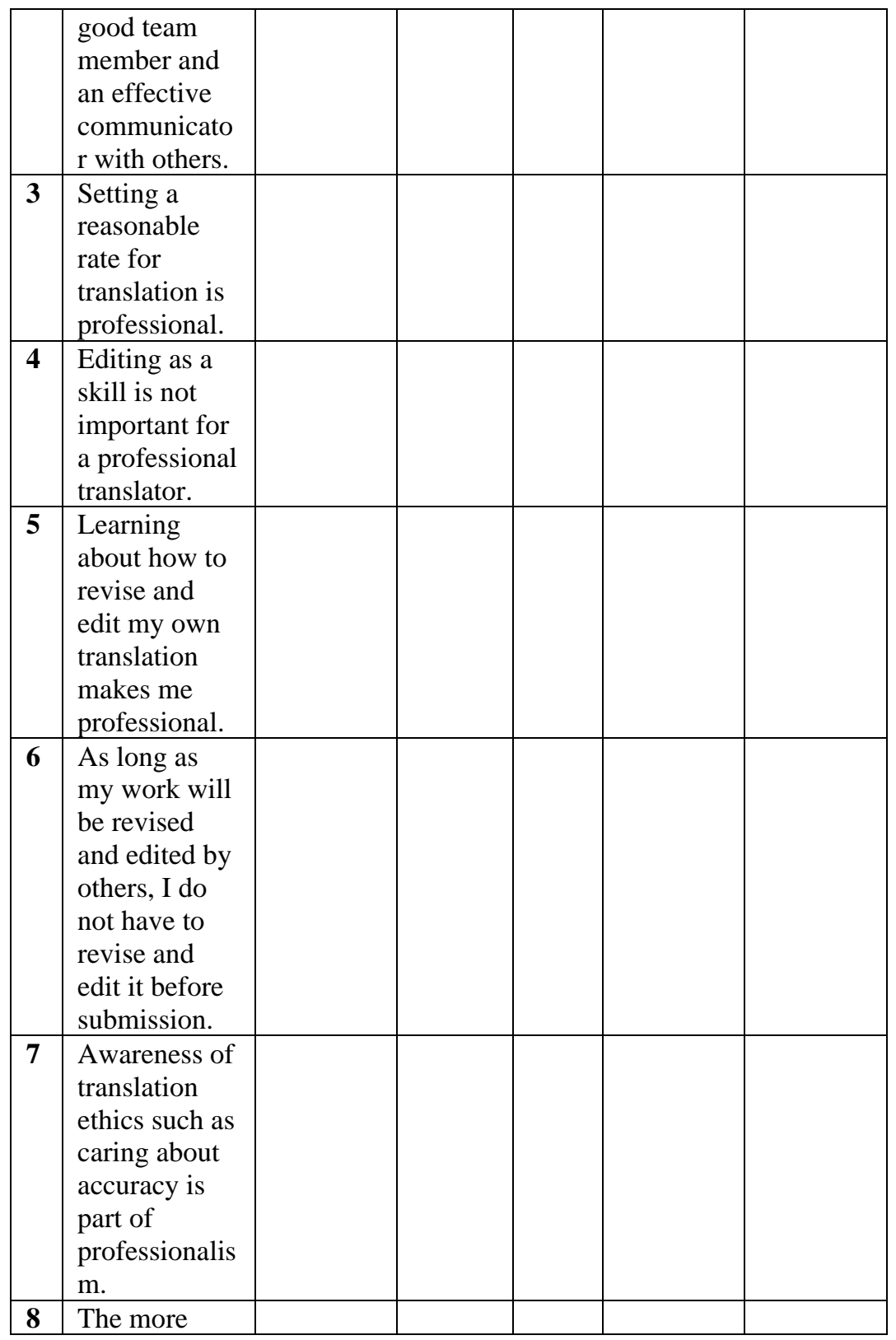


El-Hussain Aly

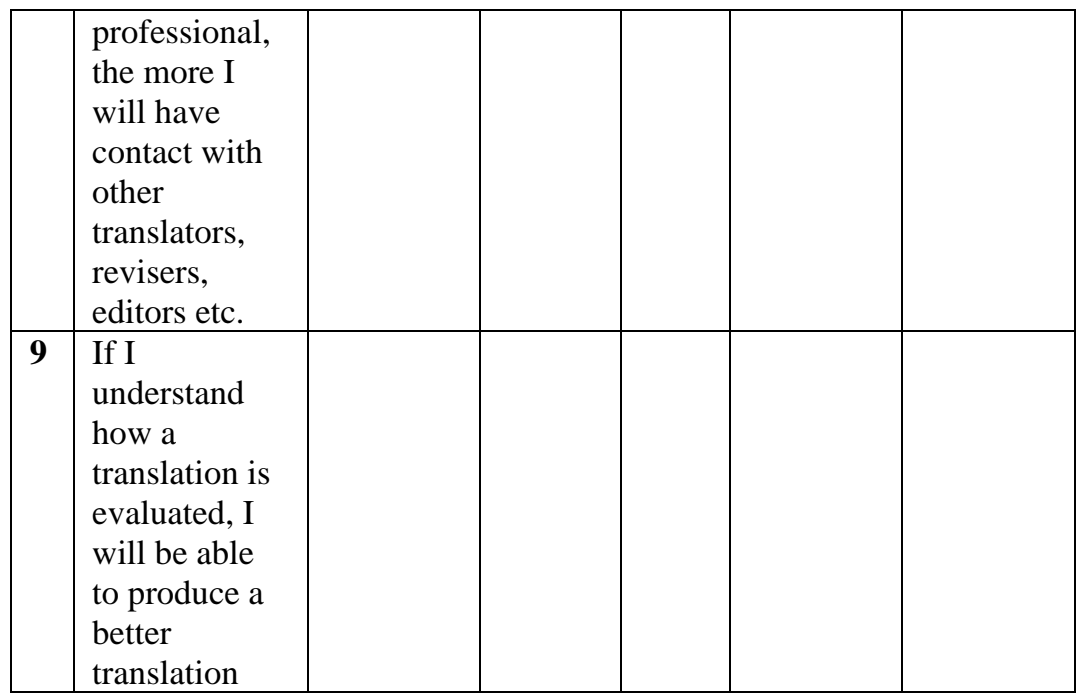

Comments and/or what makes a translator more professional?

\section{Acknowledgements}

I am thankful to all the translators and students who contributed to this research. Special thanks are due to Hala Talaat, Senior UN reviser, and Ahmed Soliha, UN reviser, Vienna Office for allowing me the chance to discuss with them the translator's competence as seen by UN revisers. 
